УДК 615.361:611.013.395]:57.086.13:612.111.7

Рогульська О.Ю. http://orcid.org/0000-0002-4757-0241, Scopus ResearcherID 56151579500

Петренко О.Ю. http://orcid.org/0000-0002-9554-8639, Scopus ResearcherID 7103293574

\title{
ВИКОРИСТАННЯ ТРОМБОЦИТАРНОГО ЛІЗАТУ ЯК КОМПОНЕНТА КРІОЗАХИСНИХ СРЕДОВИЩ ДЛЯ КРІОКОНСЕРВУВАННЯ МЕЗЕНХІМАЛЬНИХ СТРОМАЛЬНИХ КЛІТИН
}

\author{
(C) Тихвинська О. О., Рогульська О. Ю., Петренко О.Ю. \\ Інститут проблем кріобіології і кріомедицини Національної Академії Наук Украӥни, м. Харків, Україна \\ tikhvin71@gmail.com \\ rogulskaya.elena@gmail.com \\ payua@yahoo.com
}

https://doi.org/10.34142/ 2708-583X.2019.21.15

\begin{abstract}
Унікальні властивості мезенхімальних стромальних клітин (МСК) обумовлюють їх перспективність для регенеративної медицини. Стандартні методи кріоконсервування, які засновані на використанні проникаючого кріопротектора диметилсульфоксида (ДМСО) та ембріональної сироватки (ЕС), забезпечують високу виживаність клітин, але обмежують можливість їх терапевтичного застосування через ризик виникнення небажаних побічних ефектів. Токсичність високих кониентрачій ДМСО і імуногенність ЕС вимагають суттєвої оптимізації підходів кріоконсервування.

У представленій роботі проводили заморожування МСК людини у кріозахисних середовищах (КЗС) різного складу. За 24 години до заморожування у середовище культивування вносили 100 мМ сахарози для попередньої підготовки клітин. КЗС із 200 мМ сахарози доповнювали 10\% ЕС або 10\% тромбоцитарного лізату (ТЛ), у присутності чи за відсутності 1\% ДМСО. В якості негативного контролю слугували МСК, які були заморожені без кріопротекторів. Клітини заморожували у пластикових кріопробірках зі швидкістю охолодження 1 град / хв до $80^{\circ} \mathrm{C}$, а через добу занурювали в рідкий азот. Збереження МСК визначали по забарвленню трипановим синім, метаболічну активність оцінювали з використанням Alamar Bluе тесту. Під час дослідження було з'ясовано, ияо збереженість МСК після заморожування у КЗС, щчо містить 200 мМ сахарози, 10\% ЕС або $10 \%$ ТЛ без додавання

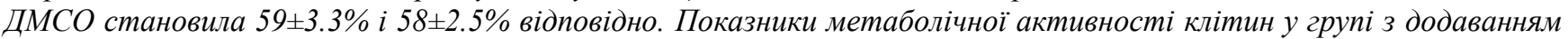
ТЛ на 12\% перевищували аналогічні результати групи з використанням ЕС. При введенні 1\% ДМСО до складу КЗС, щзо містить 200 мМ сахарози і 10\% ТЛ, показники збереженості та метаболічної активності були на 7\% $і$ 13\% вище, ніж у присутності 10\% ЕС.

Отримані результати свідчать про те, щзо заміна ЕС на ТЛ у КЗС, яке не містить проникаючий кріопротектор ДМСО, дозволяє зберегти життєздатність МСК і підвищити їх метаболічну активність після заморожування-відігріву.
\end{abstract}

Ключові слова: мезенхімальні стромальні клітини, тромбоцитарний лізат, кріоконсервування, сахароза.

Мезенхімальні стромальні клітини (МСК) знаходять все більш широке застосування у регенеративній медицині та клітинній терапії, що обумовлено їх високою паракринною активністю i здатністю до мультилінійного диференціювання. Зростаючі вимоги до стандартизації i біобезпеки клітинних препаратів обумовлюють необхідність розробки оптимальних протоколів кріоконсервування та створення кріозахисних середовищ (КЗС), що не $є$ токсичними i не містять ксеногенні компоненти.

Відомо, що для кріоконсервування МСК успішно використовують КЗС, що містять 10\% ДМСО та ЕС в концентраціях від 5 до $90 \%$. 
Тихвинська О. О., Рогульська О. Ю., Петренко О.Ю., 2019

Комбінація зазначених кріо-протекторних компонентів забезпечує високу виживаність клітин після відігріву, збереження їх специфічного імунофенотипу та здатності до спрямованого диференціювання [9]. Однак ДМСО є потенційно токсичним i здатен пошкодити клітини при використанні у високих концентраціях. Ксеногенне походження іншого ключового компонента КЗС - сироватки - підвищує ризик виникнення імунних реакцій після інфузії, а також створює небезпеку передачі різних інфекцій. Таким чином, розробка підходів, спрямованих на зниження концентрації ДМСО, i пошук альтернативи ЕC, $є$ актуальними завданнями кріобіології.

Для зниження токсичних концентрацій проникаючого кріопротектора успішно застосовують сахариди природнього походження. Їх введення до складу КЗС збільшує дегідратацію клітин та дозволяє зменшити як концентрацію, так і час взаємодії із ДМСО. На відміну від більшості традиційних кріопротекторів, сахариди можна використовувати у відносно невисоких концентраціях, що дозволяє не видаляти їх після відігрівання, таким чином, запобігаючи додаткової втрати клітин.

Серед сахаридів однією із найперспективніших для біотехнологічного застосування вважається сахароза. Доведено, що сахароза підвищує осмолярність середовища та зменшує утворення кристалів льоду всередині клітини під час процесу заморожування, забезпечуючи стабілізацію плазматичної мембрани, як позаклітинний кріопротектор [15]. Сахарозу успішно застосовують для зниження концентрації ДМСО до 5\% для біобанкінгу стовбурових клітин пуповинної крові $[15,17,19]$.

В якості альтернативи ксеногенній ЕС в середовищі культивування широко застосовують продукти на основі крові людини, в тому числі тромбоцитарний лізат (ТЛ). Тромбоцитарний лізат містить ряд біоактивних молекул, серед яких виявлені фактори коагуляції, молекули адгезії, інгібітори протеаз і протеоглікани, фактори росту ендотелію судин (VEGF), епідермісу (EGF), тромбоцитів (TGFBB), нервів (NGF- $\beta$ ) , фібробластів (FGF- $\beta$ ), фактор некрозу пухлини (TNF- $\alpha)$ та ін. $[12,4,22,10]$. В ряді робіт доведена можливість заміни ЕС на ТЛ у середовищі для культивування МСК $[1,3,20]$. Після експансії МСК у присутності ТЛ істотних відмінностей в імунофенотипі та здатності до мультилінійного диференціювання не виявляється. При застосуванні ТЛ в якості ростового компонента відмічена стимулююча дія на проліферацію ендотеліальних клітин, фібробластів і МСК різного походження.

Нещодавно було зроблені перші спроби по використанню ТЛ для кріоконсервування клітин. Поодинокі дослідження свідчать про перспективність заміни ЕС на ТЛ у складі КЗС, доповнених 10\% ДМСО [23,24]. Однак даних про застосування ТЛ при заморожуванні МСК без додавання або 3 мінімальною концентрацією ДМСО 
БІОЛОГІЯ ТА ВАЛЕОЛОГІЯ, ВИП. 21

виявлено не було, хоча створення подібних КЗС може надати можливість застосування клітинного продукту відразу після відігріву без додаткових маніпуляцій.

Метою даної роботи було дослідити збереженість і метаболічну активність МСК після кріоконсервування в КЗС, яке не містить ДМСО, де в якості альтернативи ЕС застосували ТЛ.

\section{МАТЕРІАЛИ ТА МЕТОДИ Отримання ТЛ}

ТЛ отримували із цільної крові шляхом процедури дворазового центрифугування. В результаті першого центрифугування (680 g, 15 хвилин) плазму, яка містить тромбоцити, відокремлювали від еритроцитів і лейкоцитів. На другому етапі центрифугування (2400 g, 20 хвилин) отримували концентрат тромбоцитів

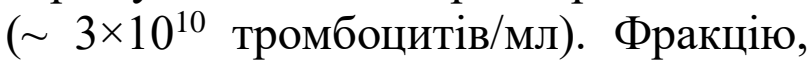
збагачену тромбоцитами, піддавали лізису шляхом триразового заморожування-відігріву та зберігали при $20^{\circ} \mathrm{C}[2,21]$.

\section{Культивування МСК}

У роботі використовували МСК жирової тканини людини 4-6 пасажів. Експансію клітин проводили при $37^{\circ} \mathrm{C}$, $5 \% \mathrm{CO}_{2}$ і 95\% вологості в середовищі $\alpha$-MEM, що містить 50 мкг/мл пеніциліну (Biowest, Nuaillé, France), 50 мкг/мл стрептоміцину (Biowest, France) і 0.2 мМ л-глютаміну (SigmaAldrich, США), а також 10\% EC (FS, Biowest, France).

\section{Попередня обробка і кріоконсер- вування МСК}

Для попередньої підготовки клітин за 24 години до заморожування в середовище культивування додавали 100 мМ сахарози. Потім, попередньо оброблені клітини трипсинізували та ресуспендували в 1 мл КЗС. КЗС складалося із середовища $\alpha$-MEM, 200 мМ сахарози, та 10\% ЕС або 10\% ТЛ. У деяких групах до КЗС додавали 1\% ДМСО. МСК заморожували в пластикових кріопробірках (NUNC, США) зі швидкістю охолодження 1 град/хв до - $80^{\circ} \mathrm{C}$ (Nalgene Mr Frosty, Sigma-Aldrich, США), а через добу занурювали у рідкий азот $[7,8]$. Кріоконсервовані зразки $\left(1 \times 10^{6}\right.$ клітин/кріопробірку) зберігали у рідкому азоті при $-196^{\circ} \mathrm{C}$ не менше 3 тижнів. Перед подальшими дослідженнями клітини відігрівали на водяній бані при $37^{\circ} \mathrm{C}$. В якості негативного контролю використовували МСК, які заморожували без кріопротекторів. Клітини, кріоконсервовані в середовищі, що містить $10 \%$ ДМСО та 10\% ЕС, слугували як позитивний контроль.

Оцінка збереженості і мета-болічної активності клітин після кріоконсервування

Безпосередньо після відігріву визначали збереженість клітин. Використовували аналіз цілісності плазматичної мембрани по забарвленню $0,2 \%$ розчином трипанового синього (ТС). Кількісно цей показник виражали як процентне співвідношення живих (не забарвлених ТС) клітин до загальної 
кількості підрахованих клітин в камері Горяєва $(\mathrm{n}=5)$.

Оцінку виживання та метаболічної активності кріо-консервованих МСК проводили за допомогою Alamar Blue тесту (Serotec Ltd, Bio-Rad, Raleigh, NC, USA). Для цього після 24 годин рекультивування, клітини інкубували в культуральному середовищі, що містить 10\% Alamar Blue протягом 3 год при $37^{\circ} \mathrm{C}$. Рівень флуоресценції розчину оцінювали за допомогою планшетного спектрофлуориметру TECAN GENios (Tecan Genios; Австрія) при довжині хвилі збудження 550 нм і хвилі випромінювання 590 нм. Відношення інтенсивності флуоресценції експериментальних i контрольних зразків (без клітин) виражали у відносних одиницях флуоресценції (RFU) $(\mathrm{n}=8)$. Клітини, що не були кріоконсервовані, використовували як контрольну групу, їх метаболічну активність вважали за $100 \%$.

\section{Статистика}

Отримані експериментальні дані мали нормальний розподіл i аналізували за допомогою t-критерія Ст'юдента із поправкою Бонфероні (для множинних порівнянь). Результати представляли як середнє арифметичне \pm стандартне відхилення. Відмінності вважали статистично значущими при $\mathrm{p} \leq 0,01$.

\section{РЕЗУЛЬТАТИ}

Після трипсинізації i до кріоконсервування збереженість клітин складала 98\% (контроль). Потім МСК були заморожені у КЗС на основі середовища $\alpha$-MEM із додаванням $10 \%$ ДМСО, $10 \%$ ТЛ або $10 \%$ ЕС. Показники збереженості клітин оцінювали безпосередньо після відігріву, тоді як метаболічну активність визначали через 24 години рекультивування.

Як видно 3 Рис. 1, після кріоконсервування в КЗС, що містить 10\% ДМСО та $10 \%$ ЕС (стандартний метод), збереженість клітин становила понад 85\%. Метаболічна активність, що була оцінена за допомогою $\mathrm{AB}$ тесту, була на 20\% нижчою, ніж у контролі. Використання ТЛ в якості компонента КЗС дозволило отримати подібні до ЕС показники збереженості та метаболічної активності клітин. Заморожування МСК без додавання ДМСО та інших кріопротекторів призводило до практично повної загибелі клітин. 


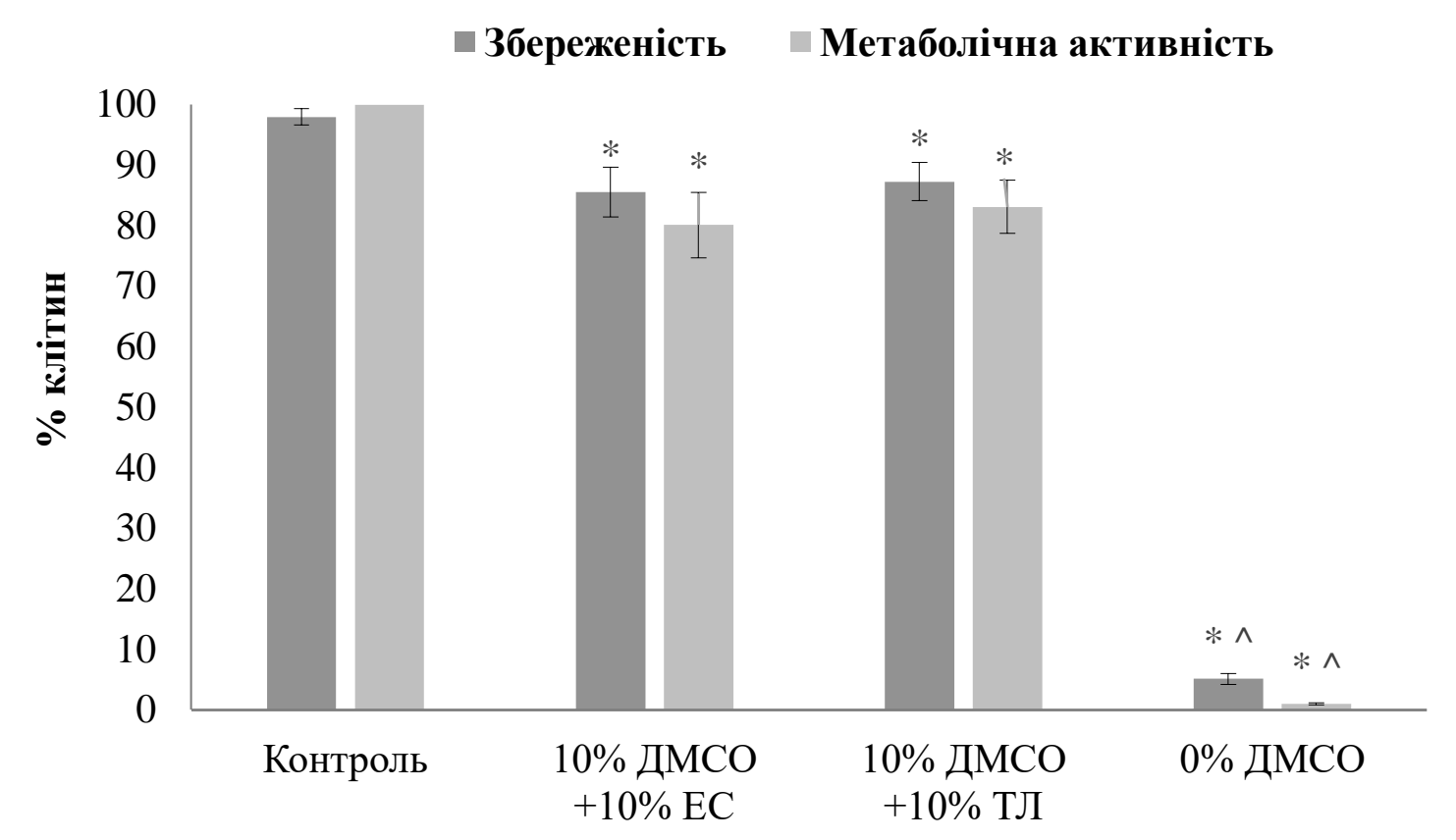

Pис.1. Збереженість і метаболічна активність клітин після кріоконсервування під захистом 10\% ДМСО із додаванням ЕС або ТЛ (* - p $<0.05$ по відношенню до групи контролю; ${ }^{\wedge}$ - $\mathrm{p}<0.05$ по відношенню до групи контролю).

Зменшити або повністю уникнути використання ДМСО дозволяє запропонований нами раніше підхід попередньої підготовки клітин шляхом культивування у присутності сахарози [14]. Для цього за 24 години до кріоконсервування до культурального середовища додавали сахарид у концентрації 100 мМ. Після попередньої обробки, клітини заморожували в КЗС, яке також містить сахарозу, в кількості $200 \mathrm{mM} \mathrm{і} \mathrm{без}$ додавання ДМСО. Цей протокол дозволив зберігти життєздатність майже половини клітин у кріоконсервованих зразках (Таблиця 1).

У наступній серії експериментів із метою зменшення коливань онкотичного тиску при заморожуванні- відігріві до складу КЗС, окрім $200 \mathrm{MM}$ сахарози, додавали 10\% ЕС або 10\% ТЛ за відсутності ДМСО. Отримані значення збереженості клітин після відігріву майже не відрізнялись для обох груп і були в середньому на $10 \%$ вище, ніж без використання ЕС або ТЛ. Однак покращення метаболічної активності клітин відмічалося лише після кріоконсервування у присутності $10 \%$ ТЛ.

Показники збереженості і метаболічної активності клітин до і після кріоконсервування у різних КЗС $(*-p$ $<0.01$ по відношенню до культивованих клітин; $\wedge$-- $\mathrm{p}<0.01$ по відношенню до відповідної групи із $\mathrm{EC)}$. 
Показники збереженості і метаболічної активності клітин до і після кріоконсервування у різних КЗС

\begin{tabular}{|l|c|c|}
\hline Експериментальні групи & $\begin{array}{c}\text { Збереженість, } \\
\text { \% клітин } \\
\text { (забарвлення ТС) }\end{array}$ & $\begin{array}{c}\text { Метаболічна } \\
\text { активність, \% } \\
\text { (Alamar Вlue тест) }\end{array}$ \\
\hline $\begin{array}{l}\text { Культивовані клітини (до } \\
\text { кріоконсервування) }\end{array}$ & $98 \pm 1.4 \%$ & $100 \%$ \\
\hline $\begin{array}{l}\text { Програмне заморожування } \\
\text { +сахароза }\end{array}$ & $47.3 \pm 5.9 \% *$ & $41 \pm 4.8 \% \%^{*}$ \\
\hline $\begin{array}{l}\text { Програмне заморожування+ } \\
\text { сахароза + 10\% ЕС }\end{array}$ & $59 \pm 3.3 \% *$ & $39 \pm 2.8 \%{ }^{*}$ \\
\hline $\begin{array}{l}\text { Програмне заморожування + } \\
\text { сахароза + 10\% ТЛ }\end{array}$ & $60 \pm 2.5 \% *$ & $51 \pm 4.3 \% * \wedge$ \\
\hline $\begin{array}{l}\text { Програмне заморожування + } \\
\text { сахароза+ 1\% ДМСО }\end{array}$ & $63.2 \pm 4.1 \% *$ & $52 \pm 5.5 \% *$ \\
\hline $\begin{array}{l}\text { Програмне заморожування + } \\
\text { сахароза+ 1\% ДМСО + 10\% ЕС }\end{array}$ & $70.0 \pm 2.9 \% * \wedge$ & $65.1 \pm 5.0 \% * \wedge$ \\
\hline $\begin{array}{l}\text { Програмне заморожування + } \\
\text { сахароза + 1\% ДМСО +10\% ТЛ }\end{array}$ & $50 \pm 3.6 \%$ \\
\hline
\end{tabular}

Отримані показники, хоч і були достатньо високими, але не досягали рівня контролю. Тому на наступному етапі експериментів КЗС було доповнено кріопротектором ДМСО в мінімальній нетоксичній концентрації $1 \%$. Додавання $1 \%$ ДМСО до складу КЗС із сахорозою, де в якості осмотичної добавки використовували $\mathrm{EC}$, призводило лише до незначних позитивних змін. У групі із ТЛ результати збереженості покращувалися на $12 \%$. Аналогічні зміни спостерігали і для показників метаболічної активності через 24 години після відігріву зразків і розсіву клітин на поверхню культурального пластику.
Кріоконсервовані МСК в процесі рекультивування були здатні до адгезії, активної міграції i проліферації. Клітини мали класичну фібробластоподібну морфологію і формували характерні «потоки». При порівнянні клітин контрольної групи та клітин після кріоконсервування значних відмінностей виявлено не було.

\section{ОБГОВОРЕННЯ}

Відомо, що класичні методи кріоконсервування, що засновані на застосуванні ДМСО, забезпечують високу виживаність клітин, але обмежують їх терапевтичне застосування через ризик розвитку небажаних побічних ефектів. Доведено, 
БІОЛОГІЯ ТА ВАЛЕОЛОГЦЯ, ВИП. 21

що ДМСО у високих концентраціях, взаємодіючи з білками і ліпідами, змінює структурні властивості клітинних мембран $[11,13,18,25]$. Для зниження концентрації ДМСО до складу кріозахисного середовища вводять компоненти, які здатні стабілізувати клітинну мембрану, вирівняти осмотичний та онкотичний тиск. 3 цією метою широко застосовують ЕС, яка, однак, містить ряд імунореактивних компонентів, здатних викликати імунну реакцію після введення [7].

Уникнути використання ДМСО у КЗС дозволяє підхід до кріоконсервування МСК, що включає попередню обробку клітин сахаридами та їх додавання до складу середовища для заморожування [14]. Дослідження показали, що застосування сахаридів і подібна підготовка клітин дозволяє зберегти життєздатність близько 50\% клітин після заморожування без ДМСО і ЕС.

У цій роботі були проведені експерименти по заморожуванню МСК жирової тканини без додавання або із мінімальною концентрацією проникаючого кріопротектора ДМСО. Збереженість клітин після кріоконсервування без ДМСО у присутності ТЛ була значно вищою, ніж у відповідній групі з ЕС. Введення лише $1 \%$ ДМСО до складу КЗС дозволило отримати понад 70\% життєздатних клітин, що хоч і менше показників контрольної групи, але близько до результатів традиційного методу кріоконсервування із застосуванням $10 \%$ ДМСО і ЕС.
Можливість використання ТЛ в якості альтернативи ЕС для кріоконсервування амніотичних МСК, МСК кісткового мозку i жирової тканини в присутності високих концентрацій ДМСО була показана у роботі Taylor et al [23]. Tolosa L. i співавт. встановили, що додаткове введення $10 \%$ або $20 \%$ ТЛ до стандартного кріозахисного середовища для гепатоцитів (середа Вісконсін і 10\% ДМСО) підвищувало виживаність клітин і сприяло збереженню їх функціональної активності після заморожування-відігріву [24].

Відомо, що основним чинником, який призводить до загибелі клітин після кріоконсервування [5, 6,] є порушення про- $\mathrm{i}$ антиоксидантного балансу, що посилює оксидативний стрес та індукує апоптоз. Активізація цих процесів обумовлена не тільки впливом низьких температур, але й безпосередньо залежить від складу КЗС. Вважається, що ТЛ у складі КЗС, завдяки унікальному набору біологічно активних речовин, має мембраностабілізуючу дію, тим самим забезпечуючи високу збереженість i метаболічну активність МСК. Таким чином, використання ТЛ дозволяє мінімізувати оксидативний стрес i пошкодження макромолекул, в тому числі ДНК, при кріоконсервуванні.

Подальше вивчення механізму кріозахисної дії ТЛ може послужити основою для розробки ефективних методів кріоконсервування, що дозволять знизити концентрацію кріопротекторів і відмовитися від використання ксеногенної сироватки. 
Тихвинська О. О., Рогульська О. Ю., Петренко О.Ю., 2019

Виходячи 3 того, що ідеальне середовище для кріозахисту повинно бути нетоксичним, не містити імуногенні елементи, але забезпечувати високу виживаність клітин, запропонований у роботі підхід по введенню ТЛ до складу КЗС із сахаридами може сприяти подальшому розвитку клітинної терапії [16].

\section{ВИСНОВКИ}

1. Заміна ЕС на ТЛ у КЗС, що містить $10 \%$ ДМСО, дозволяла зберегти понад $80 \%$ життєздатних клітин після кріоконсервування.

2. Попередня обробка МСК сахарозою і введення ТЛ чи ЕС у КЗС забезпечували високу збереженість клітин навіть за відсутності проникаючого кріопротектору ДМСО.

3. Найкращі показники збереженості (70 $3 \%$ ) і метаболічної активності $(65 \pm 5 \%)$ були досягнуті після попередньої обробки клітин сахарозою та при використанні КЗС, доповненого 10\% ТЛ, 100 мМ сахарози і 1\% ДМСО. Кріоконсервовані МСК після відігріву при подальшому культивуванні мали характерну фібробластоподібну морфологію, були здатні до міграції і проліферації.

Публікація містить результати досліджень, проведених за грантом Президента України за конкурсним проектом (Ф82).

\section{Список використаних джерел}

1. Astori G., Amati E., Bambi F., Bernardi M., Chieregato K., Schäfer R., Sella S., Rodeghiero F. (2016) Platelet lysate as a substitute for animal serum for the ex-vivo expansion of mesenchymal stem/stromal cells: present and future. Stem Cell
Research and Therapy 7: 93. doi: 10.1186/s13287016-0352-x.

2. Blande I.S., Bassaneze V., Lavini-Ramos C., Fae K.C., Kalil J., Miyakawa A.A., Schettert I.T., Krieger J.E. (2009) Adipose tissue mesenchymal stem cell expansion in animal serum-free medium supplemented with autologous human platelet lysate. Transfusion 49(12): 2680-2685. doi: 10.1111/j.1537-2995.2009.02346.x.

3. Becherucci V., Piccini L., Casamassima S., Bisin S., Gori V., Gentile F., Ceccantini R., De Rienzo E., Bindi B., Pavan P., Cunial V., Allegro E., Ermini S., Brugnolo F., Astori G., Bambi F. (2018) Human platelet lysate in mesenchymal stromal cell expansion according to a GMP grade protocol: a cell factory experience. Stem Cell Research and Therapy 9(1): 124. doi: 10.1186/s13287-018-08638.

4. Doucet C., Ernou I., Zhang Y., Llense J.R., Begot L., Holy X., Lataillade J.J. (2005) Platelet lysates promote mesenchymal stem cell expansion: a safety substitute for animal serum in cell-based therapy applications. Journal of Cellular Physiolodgy 205(2): 228-236.

5. Fu T., Guo D., Huang X., O'Gorman M.R., Huang L., Crawford S.E., Soriano H.E. (2001) Apoptosis occurs in isolated and banked primary mouse hepatocytes. Cell Transplantation 10(1): 59-66.

6. Fujita R., Hui T., Chelly M., Demetriou A.A. (2005) The effect of antioxidants and a caspase inhibitor on cryopreserved rat hepatocytes. Cell Transplantation 14(6): 391-396.

7. Goh B.C., Thirumala S., Kilroy G., Devireddy R.V., Gimble J.M. (2007) Cryopreservation characteristics of adipose-derived stem cells: maintenance of differentiation potential and viability. Journal of Tissue Engineering and Regenerative Medicine 1(4): 322-324.

8. Hunt C.J. Cryopreservation of human stem cells for clinical application: a review. (2011) Transfusion medicine and hemotherapy 38 (2): 107-123. doi: 10.1159 / 000326623.

9. Kotobuki N., Hirose M., Machida H., Katou Y., Muraki K., Takakura Y., Ohgushi H. (2005) Viability and osteogenic potential of cryopreserved human bone marrow-derived mesenchymal cells. Tissue Engineering 11(5-6): 663-673.

10. Kinzebach S., Dietz L., Klüter H., Thierse HJ., Bieback K. (2013) Functional and differential proteomic analyses to identify platelet derived factors affecting ex vivo expansion of mesenchymal stromal cells. BMC Cell Biology 14: 48. doi: 10.1186/1471-2121-14-48.

11. Lampugnani M.G., Pedenovi M., Niewiarowski A., Casali B., Donati M.B., Corbascio G.C., Marchisio P.C. (1987) Effects of dimethyl sulfoxide (DMSO) on microfilament organization, cellular adhesion, 
and growth of cultured mouse B16 melanoma cells. Experimental Cell Research 172: 385-396. doi: 10.1016/0014-4827(87)90396-X.

12. Naaijkens B.A., Niessen H.W.M., Prins H-J., Krijnen P.A.J., Kokhuis T.J.A., de Jong N., van Hinsbergh V.W.M., Kamp O., Helder M.N, Musters R.J.P., van Dijk A, and L. J. M. Juffermanset L.J.M. (2012) Human platelet lysate as a fetal bovine serum substitute improves human adipose-derived stromal cell culture for future cardiac repair applications. Cell Tissue Research 348(1): 119-130. doi: 10.1007/s00441-012-13605.

13. Notman R., Noro M., O’Malley B., Anwar J. (2006) Molecular basis for dimethylsulfoxide (DMSO) action on lipid membranes. Journal of the American Chemical Society 128: 13982-13983. doi: 10.1021/ja063363t.

14. Petrenko Y.A., Rogulska O.Y., Mutsenko V.V., Petrenko A.Y. (2014) A sugar pretreatment as a new approach to the Me2SO- and xeno-free cryopreservation of human mesenchymal stromal cells. Cryo Letters 35(3): 239-246.

15. Petrenko Y.A., Jones D.R., Petrenko A.Y. (2008) Cryopreservation of human fetal liver hematopoietic stem/progenitor cells using sucrose as an additive to the cryoprotective medium. Cryobiology 57(3): 195-200. doi: 10.1016/j.cryobiol.2008.08.003.

16. Pittenger M.F., Mackay A.M., Beck S.C., Jaiswal R.K., Douglas R., Mosca J.D., Moorman M.A., Simonetti D.W., Craig S., Marshak D.R. (1999) Multilineage potential of adult human mesenchymal stem cells. Science 284(5411): 143147.

17. Rodrigues J.P., Paraguassú-Braga F.H., Carvalho L., Abdelhay E., Bouzas L.F., Porto L.C. (2008) Evaluation of trehalose and sucrose as cryoprotectants for hematopoietic stem cells of umbilical cord blood. Cryobiology 56: 144-151. doi:10.1016/j.cryobiol.2008.01.003.

18. Rodriguez L., Velasco B., García J., Martín-Henao G.A. (2005) Evaluation of an automated cell processing device to reduce the dimethyl sulfoxide from hematopoietic grafts after thawing.
Transfusion 45(8): 1391-1397. doi: 10.1111/j.1537-2995.2005.00213.x

19. Roy S., Arora S., Kumari P., Ta M. (2014) A simple and serum-free protocol for cryopreservation of human umbilical cord as source of Wharton's jelly mesenchymal stem cells. Cryobiology 68(3): 467-472. doi: 10.1016/j.cryobiol.2014.03.010.

20. Schallmoser K., Bartmann C., Rohde E., Reinisch A., Kashofer K., Stadelmeyer E., Drexler C., Lanzer G., Linkesch W., Strunk D. (2007) Human platelet lysate can replace fetal bovine serum for clinical-scale expansion of functional mesenchymal stromal cells. Transfusion 47(8): 1436-1446. doi: 10.1111/j.15372995.2007.01220.x.

21. Schallmoser K., Strunk D. (2009) Preparation of pooled human platelet lysate (phpl) as an efficient supplement for animal serum-free human stem cell cultures. Journal of Visualized Experiments (32): 1523. doi: 10.3791/1523.

22. Shanskii Y.D., Sergeeva N.S., K. Sviridova K., Kirakozov M.S., Kirsanova V.A., Akhmedova S.A., Antokhin A.I., Chissov V.I. (2013) Human platelet lysate as a promising growth-stimulating additive for culturing of stem cells and other cell types. Bulletin of experimental biology and medicine 156 (1): 146-151.

23. Taylor C.G., Dayment R.N., Albanna M.Z., Woods E.J. (2014) Freezing and recovery of mesenchymal stem cells in human platelet lysate. Cytotherapy 16(4): S100. doi: 10.1016/j.jcyt.2014.01.371

24. Tolosa L., Bonora-Centelles A., Donato M.T., Mirabet V., Pareja E., Negro A., López S., Castell J.V., Gómez-Lechón M.J. (2011) Influence of platelet lysate on the recovery and metabolic performance of cryopreserved human hepatocytes upon thawing. Transplantation 91(12): 1340-1346. doi: 10.1097/TP.0b013e31821aba37.

25. Windrum P., Morris T.C., Drake M.B., Niederwieser D., Ruutu T. (2005) Variation in dimethyl sulfoxide use in stem cell transplantation: a survey of EBMT centres. Bone Marrow Transplantation 36(7): 601-603. 
Тихвинська О. О., Рогульська О. Ю., Петренко О.Ю., 2019

\title{
UDK 615.361:611.013.395]:57.086.13:612.111.7
}

\section{PLATELET LYSATE AS A COMPONENT OF CRYOPROTECTIVE MEDIA FOR CRYOPRESERVATION OF MESENCHYMAL STROMAL CELLS}

\author{
Tykhvynska O.O., Rogulska O.Y., Petrenko O.Y.
}

Mesenchymal stromal cells (MSCs) due to their unique properties are widely used in regenerative medicine. Standard cryopreservation methods that are based on the use of penetrating cryoprotectant dimethyl sulfoxide (DMSO) and fetal bovine serum (FS) can ensure high cell survival, but limit the possibility of therapeutic application because of the risk of adverse reactions. The toxicity of high DMSO concentrations and FS immunogenicity require significant optimization of cryopreservation approaches.

In the current study, freezing of human MSCs in cryoprotective media (CPM) with different compositions was performed. Twenty-four hours prior to freezing, cells were pretreated by addition of $100 \mathrm{mM}$ sucrose into the culture medium. CPM with $200 \mathrm{mM}$ sucrose were supplemented with $10 \%$ FS or 10\% platelet lysate (PL) in the presence or absence of $1 \%$ DMSO. The cells frozen without any cryoprotectants were used as a negative control. The MSCs cryopreserved in media containing 10\% DMSO and 10\% FS were chosen as a positive control group. The MSCs were frozen in cryogenic vials with a cooling rate of $1 \mathrm{deg} / \mathrm{min}$ to $-80^{\circ} \mathrm{C}$ with the following immersion into liquid nitrogen. The cell survival was determined by trypan blue staining; metabolic activity was assessed using the Alamar Blue test. It was revealed that viability of MSCs after freezing in CPM containing $200 \mathrm{mM}$ sucrose, $10 \%$ FS or $10 \%$ PL without DMSO addition were $59 \pm 3.3 \%$ and $58 \pm 2.5 \%$, respectively. The metabolic activity of cells in the PL group exceeded the results of the FS group by $12 \%$. When $1 \%$ DMSO was added into the CPM containing $200 \mathrm{mM}$ sucrose and 10\% PL, the cell survival rate and metabolic activity were by 7\% and $13 \%$ higher than in the presence of $10 \%$ FS.

The obtained results indicate that replacement of FS with PL in the CPM without penetrating cryoprotectant DMSO allows to maintain MSCs viability and increase their metabolic activity after freeze-thawing.

Key words: mesenchymal stromal cells, platelet lysate, cryopreservation, sucrose.

Стаття надійшла 15. 10. 2019 р. Рекомендована до друку на засіданні редакційної колегї після рецензуванн 